Marta Kurkowska-Budzan

[ Kraków ]

$\bullet \bullet \bullet \bullet \bullet \bullet$

\title{
On the Fieldwork \\ in Oral History Research
}

Wrocławski Rocznik

Historii Mówionej

Rocznik VI, 2016

ISSN 2084-0578

The most recent debates within our discipline suggest that we are at a point in which the fate of Polish oral history as a potential scientific paradigm is being decided. It might seem that a large part of the work has already been done since we have the paradigmatic tools necessary for institutionalization of the community: an association (Polskie Towarzystwo Historii Mówionej - Polish Oral History Association), academic conferences, an academic journal ("Wrocławski Rocznik Historii Mówionej" - the Wrocław Yearbook of Oral History), institutions which educate the next generation of scholars (at the history faculties of the University of Warsaw, the Jagiellonian University, the University of Warmia and Mazury, and others), scholarships for doctoral students (at the "Remembrance and Future" Center). However, these elements are of secondary significance in light of the lack of a common epistemological matrix ${ }^{1}$, which is what Piotr Filipkowski writes about when he diagnoses the "partial success of oral history in Poland":

1 T. S. Kuhn, Struktura rewolucji naukowych, Warszawa 1968; idem, Posłowie z 1969 r. do "Struktury rewolucji naukowych", "Zagadnienia Naukoznawstwa", 1 (49) (1977), p. 94-117; M. Kurkowska-Budzan, Historia zwyktych ludzi. Współczesna angielska historiografia dziejów społecznych, Kraków 2003. 
We are not "superstructuring" our documenting practices, our analyses and our theoretizing of oral history on the solid foundation of historical research which would be based on elicited sources, on witness accounts. In light of this (lack), we refer selectively, as there is no other option, to various threads within the Western tradition of oral history, to various moments in its development and to its various paradigms, adapting them to the sources we have collected (most frequently interviews we have recorded ourselves, more rarely those available in archives). This "we" that I am projecting here refers primarily to sociologists and anthropologists (ethnographers, culture experts), and to a much lesser degree to historians ${ }^{2}$.

For the formation of the scientific paradigm of "oral history", we need at the very least a common catalogue of basic epistemological objectives and the appropriate set of academic tools we ourselves would establish.

Another scenario of the development of the current situation, just as optimistic and just as probable, would be one in which oral sources would find a place for themselves anew within the historiography of contemporary history. If this were to occur (which would of course require a huge effort on the part of historians), the label "oral history" would remain attached to activities of the "public history" type.

In both these cases, as historians we must make an attempt to conduct a thorough rethinking of our cultural research practices situated within specific circumstances, establishing cognitive objectives (characteristic for history) and the appropriate methods in relation to elicited sources. In writing about "a thorough rethinking", I am referring to a return to fundamental questions and seemingly banal issues, such as, for example, permanent methodological elements which have a decisive influence on the disciplinary formation of the historian-oralist ${ }^{3}$.

In this article, I would like to present my proposal for the stipulated methodological canon for oralists ${ }^{4}$. Let me start with what remains in the

2 P. Filipkowski, Historia mówiona jako historia faktyczna. Albo jak "odantropologizować” opowieści o przeszłości?, "Rocznik Antropologii Historii”, 1 (2016) (in the process of printing, translation by the author).

3 D. Kałwa, Historia mówiona w krajach postkomunistycznych. Rekonesans, "Kultura i Historia”, No. 18 (2010), http://www.kulturaihistoria.umcs.lublin.pl/archives/1887 (accessed February 12, 2016).

4 The empirical basis of this article has been created within the research project financed by National Science Centre, DEC - 2011/o3/B/HS3/oo642. 
background of the interview itself, but which links - at least at first glance social studies researchers and historians, regardless of the epistemological objectives of their research. This would be "fieldwork".

I will begin with a thesis with which I hope the majority of my colleagues tackling oral history would agree. Much the same as contact with dusty archival documents is the initiatory experience in the formation process of a young historian, the first interview or even the first unrecorded conversation with a "witness to history" constitutes the first boundary to cross for researchers working within the oral history paradigm. A number of course books in the field provide information about what should be done and how in order to secure such a conversation, as well as on how to prepare for the interview ${ }^{5}$. These publications provide an introduction both into the very practical aspects of what should occur before, during and after the interview, as well as discuss more complex issues, not easily expressed using direct instructions, e.g. the ethical problems resulting from conducting research using the oral history method.

However, oral history methodology has a lot in common with the methodology of ethnographic, anthropological and sociological research (it might as well be stated that it is derived from these fields), and it is worth making use of some of the tools from the current achievements within these academic areas ${ }^{6}$. Or at least to consider them from time to time, taking into account the similar planes of their research experience. These planes are most frequently present at the stage of collecting material, since the choice of the analytical strategy is to a larger extent dependent on the research project objectives, and these are placed within the framework of the leading theories according to which these projects are conceptualized from the very beginning. Theoretical frames can obviously significantly condition the course of the query into the material (in the language of social studies, this would be called "gathering data"), but sooner or later things are brought down (figuratively) to a common denominator, that is we (literally) enter the "field". Fieldwork is the paradigmatic determinant of ethnography and ethnology (much the same as the above-mentioned archives are for

See: M. Kay Quinlan, B. Sommer, Oral History Manual, AltaMira Press 2009.

$6 \quad$ T. Lloyd, On the differences between folklore fieldwork and oral history, [in:] Oral history in the digital age, ed. by D. Boyd [et al.], http://ohda.matrix.msu.edu/2012/o6/ on-the-differences-between-folklore-fieldwork-and-oral-history/ (accessed February 12,2016$)$. 
a historian or a laboratory is for a physicist or chemist), and - as a result - this problem has been the subject of many theoretical and methodological discussions, and even divided cultural anthropologists and ethnologists into two camps. Among one group, the dominant conviction states that only fieldwork is a measure of the scientific value of any achievements within cultural anthropology. Among the other, that the quality of the research is not attested to by a sojourn in the field or the amount of data collected, but rather by the innovative theory about culture ${ }^{7}$. Similar debates within contemporary historiography seem not to be justified as well as no one would question the formative function of archive queries in the shaping of independent and creative historical writing.

On the other hand, within the realm of oral history the discussion has been on-going since its very beginnings and the issues of the narrator, narrative and the role the researcher has within the dialogue that occurs between him or her and the interlocutor continue to be debated. However, methodological considerations concerning the equally important "field" and its place within our discipline have never reached the scale they did among anthropologists ${ }^{8}$, despite the fact that we find ourselves in the "field" on a daily basis. I do not have the relevant statistical data at my disposal, but I am convinced that the vast majority of "witnesses to history" do not come to us, instead we travel to see them, to their hometowns and to their natural environments. We move at least across space if not between cultures ${ }^{9}$. Why should the "field" have the same significance within our historical research? I hope to explain this within the next few pages.

In these divagations concerning the methodology of oral history, the focus is - as mentioned above - on the interlocutor or at times on the dialogue

7 A. P. Kowalski, Antropologia kulturowa jako nauka historyczna, [in:] W krainie metarefleksji. Księga poświęcona profesorowi Czesławowi Robotyckiemu, ed. by J. Barański, M. Golonka-Czajkowska, A. Niedźwiedź, Kraków 2015, p. 143-152.

8 See: Teren w antropologii. Praktyka badawcza we wspótczesnej antropologii kulturowej, ed. by M. Buliński, M. Kairski, Poznań 2011; C. W. Watson, Being There. Fieldwork in Anthropology, London 1999; Obserwacja uczestniczaca w badaniach historycznych, ed. by B. Wagner, T. Wiślicz, Zabrze 2008.

9 See: L. Niethammer, Where were you on 17 June? A Niche in memory, [in:] International Yearbook of Oral History and Life Stories, 1: Memory and totalitarianism, ed. by L. Passerini, Oxford-New York 1992; R. Perks, Ukraine's forbidden history. Memory and nationalism, "Oral History", Vol. 21 (1993), No. 1. 
between two people. I consciously use the term "people", because we the researchers are acutely aware that an interview is a meeting between two persons - two personalities, in the sense of a specifically organised set of intellectual, emotional, temperamental and volitional features ${ }^{10}$. Contemporary oral history research, which focuses its attention on autobiographical narratives, is interested both in its structure and in the interlocutor's "life experiences". This life experience shapes and changes one's personality and identity, and it is at the centre of both academic analysis and is dominant at the query phase. It would be easy to write, taking into consideration our initiatory experiences, that especially young researchers are greatly under the impression of this first contact with a narrator, but I am of the opinion that this statement would be neither honest nor true. All of us, regardless of how many interviews we have conducted and how many years we have worked in the field, are the subjects of interactions and we react to the personalities we encounter. Therefore, in our methodological texts, we devote a large amount of space to interpersonal relations in the course of an interview (also before and after the conversation). In most cases the situation involves the relation between two people, but frequently we encounter larger groups - a family, a group of friends or members of some social group.

However, the "field" signifies something more than just our interlocutors, and most of us are undoubtedly well aware of this fact. It is impossible to ignore the physical space which we enter in a specific way or the fact that our very presence creates a new element within a given community and culture, and also that this has some - perhaps quite minimal - consequences for the community and vice versa. Again, some might say that this is a well-known issue for ethnologists and that a multitude of texts have been written on the subject. Are we therefore making an attempt at reinventing the wheel?

It seems to me that there is a need to discuss this issue for at least one reason which is of an epistemological dimension and which reveals itself as the first aspect already at the stage of conceptualizing the research and organizing the project. It is thus both first in temporal terms and fundamental for the academic research objectives. A historian who is focused on some cognitive queries and is at the stage of organizing his or her work

10 N. Sillamy, Stownik psychologii, Warszawa 1994, p. 193. 
12 has a two-pronged approach. On the one hand, he or she considers the subject which torments him or her intellectually (can it be done and how) and thinks about the sources on which his or her research will be based. In the case of traditional documents stored in an archive, one has to solve such issues as where they can be found, how to get to the archive and how much time should be spent on the query. The contact itself with the archive or even with a menacing archivist is not much of an academic challenge for a historian, since the success of the first stage of this activity is dependent on one's knowledge of the principles of how an archive functions and which are more or less convergent (though of course there are certain glaring exceptions to this rule). This practical knowledge accumulates over the years and with time there is very little that can surprise a historian in an archive. It is not without reason that experience in conducting queries in archives is so highly valued among historians - the subsequent academic endeavours of a researcher are executed with increasingly more efficiency, they have a "low risk factor" and they provide a guarantee of achieving the stipulated research objectives.

A historian who shows a preference for oral sources over documents, regardless of whether he or she is set on working in a specific place (municipality, environment, institution, etc.) or on making a query which would be geographically and environmentally dispersed, cannot count on any permanent, universal and independent rules which would allow him or her to consistently pursue the achievement of a complete query of the available sources. Our sources, even if they are ostensibly limited (for example, by the amount of inhabitants or members of a veteran association), do not constitute a described inventarized group that has a defined size in linear metres. No such archivist exists that could provide us with a guarantee that our "stock of sources" has been checked in its entirety. We have no certainty "that was everyone", that we talked to each and every person involved (some identified potential interlocutors may refuse, while we might be unable to contact others, and of course it is always possible we simply do not know some exist). Not to mention that no one verifies whether we have been able to "decipher" our sources in their entirety, i.e. whether everything has been said.

When planning to come into contact with an oral source, a historian must cast his or her gaze on more than just this selected fluid "resource". It is up to him or her to define the "field", how he or she will percieve it and what cognitive potential he or she will see: will the "source material" come only in the form of the interlocutor or the entire environment, culture? And if the latter, what does he or she actually understand under these 
terms and how should he or she translate this into practical preparations for the project? In the minimalistic version, before a historian contacts his or her interlocutors, he or she should establish first contact with the key informant. The process strategies (of acquiring interlocutors) have been described in most oral history course books, and in the cognitive context that interests us (the key informant, snowball sampling, the insider-outsider perspective, etc.). Of course, it is recommended that one should acquire as much knowledge as possible on the biography of a person one is planning to interview. If it is a war veteran, we should become well-acquainted with the chosen historical period, with the history of his or her unit and the history of the military campaigns in which he or she might have participated. Every oral history course book teaches the need for such preparations. I have not, however, encountered similarly detailed advice concerning other types of preparation for conducted fieldwork, such as, for example, before an excursion to a particular municipality. It would seem quite obvious, amounting to reading the basic literature on the history and contemporary situation in the region, the geographic and economic conditions, the social relations, etc. Perhaps an assumption is made, probably justifiably, that such preparations have as much significance for the logistics of the endeavour as in the case of any such trip, for example, as a tourist, and there is no need to devote space to this issue in methodological course books. However, this is a clear expression of the fact that we limit our cognitive perspective to the "human resource as source material", while at the same time we isolate out our interlocutors from their relevant space, context, environment and - in fact - from the very lives they now lead. I will return to this statement in due course.

Secondly, the field - physical space, images, sounds, smells, events, the people we encounter after arriving at the place of our research and while we are heading toward our first meeting with our interlocutor - these are all impulses which influence us and from the very beginning shape both the conditions and cognitive horizon of our research. From the very beginnings of their discipline, ethnologists have been aware that their research was being conducted among "others"; whereby the otherness of the cultures they were studying was marked in every fragment of the surrounding reality. When getting onto a local bus from Łomża to Kolno (Mazowsze region, north-eastern Poland), where I am to conduct an interview, am I actually crossing some cultural boundary that should lead me to exercise vigilance concerning what will be going on around me from this moment onwards and which might constitute research material for me and/or influence my 
research? I am going to a small town with ten thousand inhabitants, the capital of the poviat, and I will be travelling by a vehicle owned by the carrier most often used by the residents of Kolno to get to Łomża, which is five times larger, where they study, work, do their daily shopping and participate in leisure activities (in the cinema which Kolno does not have). However, my project is not focused on contemporary Kolno but on its history - I am intent on studying a time in which no one even imagined that any private entrepreneur would offer transportation services. The reality which interests me is that of the period between 1944 and 1989 - a different economy, culture, mentality, a time of other customs and a completely different material situation. Today Kolno looks different; there are new streets and squares, while the old ones have changed their names. Characteristic landmarks in the town around which the stories the narrators tell revolve, now perform other functions or no longer exist. However, I arrive at these facts not on the basis of my conversations, but during the walks I take with my interlocutors around the town and during my lone explorations of the space, when I take photographs of the current life of the town. This is not fully participant observation, but rather opening oneself up to external impulses in order to better understand the interlocutors' perspectives, the mental shortcuts they use, their language. But also in order to be able to ask further questions, to enter their symbolic reality, to come to an understanding of what once held and what now holds some significance for the inhabitants of Kolno and what that significance is. On the bus I have already taken twice, I now know how to behave, I know the most popular topics of social conversation in the 2014 season and I can use some of the local expressions correctly. Does this sound like studying a foreign culture yet? I have acquired some knowledge of the area, including the shape of the terrain and the distances from Kolno to the surrounding hamlets and villages which are important for my research. On the bus I also find out about the shortcut used to get to a place I cannot find on any of the maps of Kolno, but which is continuously mentioned in the stories I am told under the name "Wiżałki" or "Wiszałki". This is a small wood, at one time a young coppice, that before and after the war had been a favourite place of leisure for the inhabitants of Kolno. Only after I have gone there for a walk and returned to the old town centre (with a watch in my hand) will I be able to create an temporal and spatial image of Kolno many years earlier; and to write into this image the people who in subsequent decades pursued various sports in this provincial town, as well as understand their current reflections about the past. 
In the above fragment, I have not been able to separate out the thread of physical space from that of the culture of the area - much like it is not possible to separate them out in the course of on-going perception. Travelling by bus through the picturesque hilly surroundings of Kolno, I take part in the communal conversation among the passengers, adopting the locally valid style of conducting small talk in public transportation vehicles, while simultaneously observing the villages we pass and noting the changes in the architecture, methods of administering the area, and in the lifestyles. The material culture of this region is obviously a palimpsest - it can be deciphered with the naked eye; the layers are perfectly visible, each one breaks through the others or they co-exist. As a result, a historian can ascertain with his or her own eyes what has changed and how over time. This facilitates the basic work done with the interlocutors' memories - it enables situating them within a specific geography, setting and civilisational context. In the analysis of autobiographical narratives, it aids in understanding the interlocutor's world and viewpoint. The interlocutor's personality and outlook on life was formed in a specific place (or many places) over the course of time, while its present form - which we encounter during the interview - also functions within a specific space. This space is, as Rapoport wrote, simultaneously three-dimensional physical space and an environment filled with meanings ${ }^{11}$. In order to understand a narrator and his or her story, we first need to acquire knowledge of the story in all its dimensions, beginning with the physical basis.

A historian in the field comes into daily contact with people who - aside from the narrators themselves - are literally and metaphorically passersby. Such transient meetings, conversations, observations shape our cognitive horizon, but they also raise our research competences. As a result, we learn the local - verbal and visual - language, and the metaphors from which the symbolic tissue of the terrain is woven.

Countless examples could be cited which I consider significant for the epistemological dimension of research, the value of what I would call "conscious presence in the field". However, since I have been complaining about the lack of practical instructions concerning what should be done with the accumulation of valuable impulses while conducting fieldwork, let me

11 A. Rapoport, Human Aspects of Urban Form. Towards a Man-Environment Approach to Urban Form and Design, Pergamon Press 1977. 
move on to more direct statements. In order for "conscious presence in the field" to bring academic results, it must be situated within scientific procedures, which - by virtue of tradition - primarily presumes verbalisation, normalisation of forms and systematisation of content. These three conditions can be fulfilled with the help of the so-called research diary. Once again, sociologists from the qualitative sociology school, ethnologists and ethnographers have been well-acquainted with this tool for many decades. Thanks to various prominent ethnographers, the research diary has all but risen to the status of a work of literature, while simultaneously provoking much controversy and countless discussions among subsequent generations of researchers ${ }^{12}$. The contemporary fieldwork diary can theoretically take on various forms - from the classical notebook or pile of flash cards, to textual electronic documents or blogs, and also audio and video recordings. It can of course also constitute a mix of genres or transgress beyond them. For example, in September 2001 I was on a scholarship at New York University. During the attacks on the World Trade Center and over the course of the next month, I provided long accounts of what was going on in the direct vicinity of my place of residence and my workplace on $3^{\text {rd }}$ Street in Lower Manhattan in the form of long e-mails to a friend - a social anthropologist. I have saved copies of these letters and today they constitute a form of documentation which - when compared to the press accounts at that time or academic studies conducted soon afterwards - have the advantage of being a politically and ideologically untainted diary involving participant observation.

From my own experience and as a result of the personal preferences of a person born in the previous century, it seems that the easiest form of diary, which works in any conditions, in any terrain, a "four-wheel drive" diary, would be a thick spiral notebook with a hard cover. The situation in the bus was written down not long after it occured, while sitting in a roadside ditch; the observations I had in a church were also written down quickly in the shade of a confessional booth. While one may put a lot of trust in one's memories, when it comes to recording impressions and not facts, it is best

12 See: B. Malinowski, Dziennik w ścistym znaczeniu tego wyrazu, Kraków 2007; G. Kubica-Heller, Dlaczego warto czytać dziennik Bronisława Malinowskiego? Wyodrębnienie sprężyn życia, "Tygodnik Powszechny”, No. 22 (2002); eadem, Joanna Tokarska-Bakir, czyli paradoks lektury niechętnej, "Res Publica Nowa”, No. 1 (2003); J. Tokarska-Bakir, Malinowski, czyli paradoks kłamcy, "Res Publica Nowa", No. 11 (2002). 
to document them then and there. In the case of a research diary, the idea is to write down anything important that occurred or that in our opinion is lacking in what surrounds us, within this "foreign culture". Unfortunately, this is a time-consuming task, but the investment of time is returned a hundredfold, even if we do not manage to continue the writing of the diary until the end of the research project, regardless of how heretical that sounds. However, I am of the opinion that these moments of observation and perception of the terrain are incremental when we are taking our first steps into a "foreign land" or, as Krzysztof Konecki writes, when we plunge into a world of symbolic images and sounds ${ }^{13}$. It is precisely the things which make us wonder, which surprise us, which make us stop and think or - conversely - which seem to be strangely familiar, that should be written down and analyzed. The subsequent phase of research, when we are becoming acquainted with the topography of the place and have already completed our first two or three interviews, is abundant in more coherent notes. At this point, we are capable of formulating interpretational accounts of the space around us and the relations between facts, decipher symbols and situate them in relation to what we have heard during both recorded conversations and the more spontaneous talks which occur during our stay in a given town. This is the first attempt at academic deciphering of the field. In the process, we acquire a sense that we actually know and understand what the next story will be about. This makes it possible to construct additional questions and the questionnaire may undergo extensive revisions, including modifying the topic that had initially interested us. At this stage, there is a lot of willingness to sit down in the evenings and summarize the data, and it is precisely the various notes taken that might turn out to be exceptionally valuable during the final analysis we will be conducting at a distance from the place where the research was carried out.

A research diary is an inostensible yet demanding scientific tool. Firstly, it tests how methodical we actually are. Secondly, it forces us to sharpen our senses, to open ourselves up to external independent cognitive impulses, which in contrast to "elicited sources" or narratives cannot be placed under our control. Or at least they do not provide us with any illusions that we do have such control. A single observation and a record of it in our diary

13 K. Konecki, Studia z metodologii badań jakościowych. Teoria ugruntowana, Warszawa 2000, p. 31, 91, 96. 
can effectively sow coginitive doubt (oft-times very needed in the humanities), or scuff up dust on the route which had been traced at the beginning of the study and was supposed to have led us straight to a foreseeable destination. A research diary is a normalized procedure, which through verbalisation and systematic notation of equally systematic observations constitutes a type of footnote to the academic text. Such a diary provides the opportunity, much as in the case of a footnote, to verify the source and to conduct an evaluation of our interpretation of a given issue.

Regardless of whether we are interested in past experiences represented in autobiographical narratives, or in their structure, or whether we are searching for knowledge about historical facts within oral accounts, such literal and cognitive "wanderings" across the field, situated within the rigor of a systematic research diary, should provide satisfying academic results. It would be worthwhile to include the ethnographic tradition of treating the field as "a humanistic whole which becomes realized in people's experiences and actions and in the spatial entirety embedded in specific environmental circumstances"14 into the permanent formational methodological "oral history" repertoire for young researchers.

14 I. Sagan, Miasto - scena konfliktów $i$ wspótpracy. Rozwój miast w świetle reżimu miejskiego, Gdańsk 20oo, p. 30 (translation by the author). 
The article concerns the problem of a lack of both academic tools as well as a catalogue of basic epistemological objectives that could serve oral history in Poland. It has to be stated, however, that there are already many institutions, conferences and journals, that focus on the issue of oral history. The author proposes some solutions that could improve this methodological gap, based on her own experience in oral history, such as introducing a research diary as a scientific research tool.
Marta

Kurkowska-Budzan

On the Fieldwork in Oral History Research 